\title{
Better Life Index and Health Care Quality Indicators, Two New Instruments to Evaluate the Healthcare System
}

\author{
Paolo Pietro Biancone ${ }^{1}$, Silvana Secinaro ${ }^{1} \&$ Valerio Brescia ${ }^{1}$ \\ ${ }^{1}$ Department of Management, University of Turin, Turin, Italy \\ Correspondence: Valerio Brescia, Department of Management, University of Turin, C.so Unione Sovietica 218 \\ bis, Turin, Italy. E-mail: valerio.brescia@unito.it
}

Received: November 5, 2017

Accepted: December 13, 2017

Online Published: January 15, 2018

doi:10.5539/ijbm.v13n2p29

URL: https://doi.org/10.5539/ijbm.v13n2p29

\begin{abstract}
Local health companies have been trying to report quantitative and qualitative information through social reporting tools for a long time. The OECD has been questioning for quite some time how to evaluate satisfaction and quality by not considering the economic aspect alone in the quest for satisfying the needs of the citizen. The aim of the work is to evaluate how the compound indicator of well-being perceived by the population and the composite indicator of the quality of health services can be used to define health policies considering the incidence of other variables. In the analysis, it is therefore assessed how much the two indicators are related and linked to other variables that need to be considered and how independent indicators are used without further evaluations to target policies. The data are updated to October 18, 2017. All statistical analyses were performed using STATA V.13 (Stata Corp, College Station, Texas, USA, 2013) and p value $<0.05$ was considered significant for all analyses. The sample is made up of 35 OECD countries.
\end{abstract}

Keywords: better life index, healthcare policy, healthcare quality, indicators compounds, public decision, welfare, OECD

\section{Introduction}

\subsection{Theoretical Reference Framework}

Managerial business studies (Ferrero, 1987) distinguish entrepreneurial realities with respect to the object of business carried out in companies for the production of goods and services for the exchange of market (or business) and supply companies or consumer companies (Puddu, 2001). The distinction between supply and business companies is needed as a theoretical reference model but from the moment when consumer processes, production, acquisition, storage and distribution are common to all companies, the division is often not so clear between "pure" consumer company and "pure" business (Puddu, 2001). Since the 1980s, the corporatization of healthcare companies has led to the identification of indicators to assess the relapse of the structure during the phases aimed at responding to public needs (Preker \& Harding, 2003). Berntzen demonstrated the centrality of public opinion for public administrations in the provision of service, this basic theory can be identified in the trend called "New Public Management". The government in particular should see citizens as customers and suppliers at the same time, thus defining the level of service as it does when it comes to private companies. Information needs are also perceived not only in the internal front, in the process of planning and controlling the activities of public companies, but also externally, as a tool of responsibility towards the citizen / user (Rainero et Brescia, 2016). The most significant issues that have provoked intense organizational innovations in the governments of public companies are represented by greater independence from political power, independence has gained power to exploit service regulation in response to user's expectations, and in operational terms, through an ever-closer confrontation with the private enterprise or with the public at international level (Farneti 1993). Local health companies have been trying to report quantitative and qualitative information through social reporting tools for a long time. The colloquial documents represent an important communication tool that helps to describe the results; with the aim of analysing output also from the cost-effectiveness point of view, increasing the evaluation capacity in a social dimension (Biancone, Secinaro, Brescia 2016). The citizen increasingly defines himself as a bearer of active interest in defining public policies (Tanese 2005; Sancino 2010; Costa and Tafuro 2013). This assumption results in a high complexity for public administrations to ensure the pursuit of public interest by guaranteeing transparency (Borgonovi 2004; Cristofoli et al., 2010; Ditillo et al., 2014). 
Historically, transparency advocates saw it first and foremost as a necessary component of democratic self-government. Transparency about governmental policies and activities allows democratic citizens to make more informed decisions about how to govern themselves. More recently, this principle was extended into the private sector, to include information that individuals could use in regulating the market and as consumers of its products and services. In recent years, however, many advocates of transparency have come to expect the forms to yield highly tangible and concrete results by resolving specific concerns of governance and government performance. Many now see transparency's potential to catalyse improvements in areas such as healthcare outcomes and educational quality, leading to measurable improvements in citizens' capacities and well-being. The expectations for consequential transparency are far more ambitious, practically and social-scientifically, than citizens' deontological "right to know" (Kosack \& Fung, 2014). Transparency is also ensured by identifying members or figures assigned to government supervision at all stages of the production process (Alfiero \& Secinaro 2010). This translates into an increasing demand for responsibility (Freeman, 1984) in the multiple meaning of responsibility assumption, attention to transparency, enhancement of participation and stakeholder engagement (Freeman et al., 2010). Therefore, in the analysis, it was highlighted which tools are useful to provide reading keys with respect to the quality and perception of the same by citizens in local health and hospital services. The citizen (Biancone et al. 2016) as well as sometimes the other stakeholders and shareholders (Epstein \& Palepu, 1999) have difficulty in reading budget outcomes and need other non-economic tools to comment on and understand public investment in this context, to this aim it is necessary to identify alternative and explanatory indicators other than strictly economic ones. Since the end of the 1960s, we have been moving slowly and gradually from an objective and monetary vision to a subjective one with a greater focus on social reality. It is in this revolutionary context that the so-called "Social Indicator Movement" is animated, by testing the planning at a global level of markets recipient of economic growth. Scientists, politicians, and sociologists consider social sustainability and well-being as the bond of society to common goals, the participation of society in the democratic process, governability and access by the population to education, food, health services, etc. (Colabrò \& Della Spina 2016, de Carvalho 2001). For a couple of decades, sociologists and psychologists have worked together to develop indexes that reflect the most representative living quality developments of gross national product statistics. "The Formula of Happiness" has already been invented by combining different criteria of measuring well-being with the measures of personal perception of individuals on their own situation. Most of these studies describe the main determinants of economic performance on competitiveness and the interdependence between the current socio-economic development of a country and its potential growth. In February 2008, French President Nicholas Sarkozy created a committee called "The Committee on the Measurement of Economic Performance and Social Progress", led by Joseph Stiglitz, and advised by Amartya Sen. The Commission's objective was to " identify the GDP limit as an indicator of economic performance and social progress, including the problem of its measure. " The committee also sought to consider what further information is needed to produce the most important indicators in order to achieve social progress; to consider the feasibility of alternative measurement tools, and to discuss how to introduce statistical information in an appropriate way. The real difficulty already encountered, was among the official keys of measurement and widespread perception. The first document that the committee did, gave a list of advice and, finally, judgment tools. Greater emphasis on income and their use has been attributed, rather than to production, to greater reliance on households, rather than the whole economy, and wealth and income. Finally, the document claims to be able to read the sustainability and wealth of citizens through a 'dashboard of indicators'. Gross national product is the most used indicator in the measure of economic activity, but has various shortcomings. It only measures market production without making use of market prices, and does not take into account the surplus of the consumer or of produced externalities. But the current recession is not because we have not been able to follow the kind of advice given by this Commission; the current recession is a periodic process and is part of the nature of the economic system (Leunig, 2011). The problem is that wealth is extremely difficult to measure. The report recognizes that human capital is difficult to measure, and that for a lot of people competence is the most important wealth they have, and this is an unlikely representative factor of well-being. Large-scale official surveys must be communicated to the territory, because people's happiness, their hedonistic experiences and their priorities change. Many governments have radically changed output to offer different preferences, it is difficult to imagine that this type of investigation could be internationally standardized in a useful way, as for standardized national accounts that are the basis for GDP evaluations, but OECD European projects are moving in this direction. We must also note that the creation of too many indexes from the created commission could make the report difficult to interpret and not generalizable, once again giving the role of GDP as the main indicator of comparison. The Commission's report on measuring economic performance and social progress is vaguely interesting, but gives little in terms of economic historical value. It does not give timely alternatives as 
to how different companies have made actions based on different indexes. It has been estimated that, taken as a whole, changes in per-capita GDP could overstate or underestimate social progress developments economically, or that this measure is more or less accurate according to the different countries or the different time periods considered. Indicators and composite indexes are increasingly recognized as useful policy tools for bringing information about a country's performance towards their specific goals within the three main aspects of sustainability (quality of the environment, social equity, and economic well-being). The main advantage of an indicator is its ability to summarize complex information of our world dynamically and in quantities both manageable and meaningful for immediate analysis. There are no ideal planning tools to achieve sustainability either on a regional scale or on a local scale (Keiner, 2006). Recently, politicians have begun to encourage scientists to improve models for the development of new integration and quantitative and qualitative analysis techniques for local and regional planning for sustainable development (Grosskuth 2007). In order to achieve success in planning at any scale, appropriate methods, procedures and instructions are mandatory (Keiner 2006). In particular, the right choice of indicators is essential to oversee progress towards sustainable territorial development. In 2015, a survey of 25 composite indicators allowed to analyse and compare 36 countries in Europe, highlighting how it can be possible to group into clusters of countries in 4 homogeneous categories. Some research states that it is not possible to compare individual countries, but across homogeneous cluster groups (Shaker \& Zubalsky 2015). But since 2011 there is the "Better Life Index" project that provides several indicators to analyse the situation of all OECD Countries. The Better Life Initiative (literally, "initiative for a better life") provides statistics to measure the aspects of life that count for citizens. This allows a better understanding of what determines the well-being of people and nations and what needs to be done to ensure more progress. Inspired by the Commission's recommendations on measuring economic performance and social progress, the OECD has identified 11 essential wellness dimensions ranging from health and education to the environment, to security and overall satisfaction for the own life, also taking into account more traditional parameters such as income. The two main elements of this OECD initiative in our analysis are the How's Life Report ("How is life")? and the Better Life Index, that is the index for measuring the quality of life.

\section{Methodology}

The aim of the work is to evaluate how the compound indicator of well-being perceived by the population and the composite indicator of the quality of health services can be used to define health policies considering the incidence of other variables. In the analysis, it is therefore assessed how much the two indicators are related and linked to other variables that need to be taken into account and how independent indicators are used without further evaluations to target policies. In order to correct the possible distortion in considering the relationship between the dependent variable (health perception indicator) and the other variables we use the average available income variable of families in each country and the variable related to the perceived quality of health indicator, we also take into account the social inequality in each country and the age-dependent demographic relationship (defined as the number of individuals over the age of 65 for 100 people, depending on the percentage of people working in the age range between 20 and 64 years old). The relationship between perceived well-being or happiness and social inequity has already been analyzed in several studies and it is used also for our analysis (Blanchflower \& Oswald, 2004; Graham \& Felton, 2006). Several values have been eliminated as they affect the perception of health and life expectancy (number of hospitals, nurses, technical staff, beds, technological levels). No indicators have been evaluated that affect the life expectancy indicator (nutrition, type of work, consumption of substances harmful to the body). Furthermore, the different organization regarding the health system of each national is not taken into account, because the social indicator has been assessed through the same criteria in all countries. The analysis will firstly assess: 1) the correlation between the 2013 life expectancy indicator and the OECD framework and quality indicators. 2) An assessment will be made of the relationship between the dependent variable of perception of health for the year 2013 and two independent indicators such as quality indicator and life expectancy indicator for the population. 3) For 2013, the relationship between quality indicator and current expenditure on total health expenditure per nation is assessed. 4) The relationship between a 2013 health indicator and current expenditure percentage on total expenditure in national health care will be assessed and 5) The relationship between 2013 quality indicator and current expenditure on total national health expenditure (Table 1). In order to assess the autonomy of the composite indicator on the perception of health compared to other independent variables, an OLS was evaluated with the 6) relationship (life expectancy, millions of inhabitants, available family income, total inequality indicator, percentage of dependency on retirees), 7) linear correlation between the percentage of current spending in the healthcare sector on the total expenditure of each national. Values for the year 2016 were taken into account (Table 2). All analyses were verified with a robustness test that confirms the significance of the relationships. The data are updated to October 18, 2017. All 
statistical analyses were performed using STATA V.13 (Stata Corp, College Station, Texas, USA, 2013) and p value $<0.05$ was considered significant for all analyses.

Table 1.

\begin{tabular}{|c|c|c|c|c|}
\hline & Health perception 2013 & Life expectancy 2013 & Quality indicator 2013 & Current health spending $\%$ on total spending 2013 \\
\hline Australia & 85 & 82 & 4.1 & 8.81 \\
\hline Austria & 69 & 81.1 & 10 & 10.19 \\
\hline Belgium & 73 & 80.5 & & 10.37 \\
\hline Canada & 88 & 81 & 6.7 & 10.12 \\
\hline Chile & 59 & 78.3 & & 7.29 \\
\hline \multicolumn{5}{|l|}{ Czech } \\
\hline Republic & 59 & 78 & 6.7 & 7.72 \\
\hline Denmark & 70 & 79.9 & 5.7 & 10.21 \\
\hline Estonia & 51 & 76.3 & 11.5 & 6.02 \\
\hline Finland & 69 & 80.6 & 6.5 & 9.49 \\
\hline France & 67 & 82.2 & 7.2 & 10.93 \\
\hline Germany & 64 & 80.8 & 8.7 & 10.97 \\
\hline Greece & 76 & 80.7 & & 8.34 \\
\hline Hungary & 55 & 75 & & 7.29 \\
\hline Iceland & 77 & 82.4 & 6.4 & 8.70 \\
\hline Ireland & 83 & 80.6 & 6.7 & 10.42 \\
\hline Israel & 82 & 81.8 & 5.5 & 7.08 \\
\hline Italy & 64 & 82.7 & & 8.95 \\
\hline Japan & 30 & 82.7 & 8.3 & 10.79 \\
\hline Korea & 37 & 81.1 & 15.4 & 6.91 \\
\hline Luxembourg & 72 & 81.1 & & 6.55 \\
\hline Mexico & 66 & 74.2 & 28.2 & 6.01 \\
\hline Netherlands & 76 & 81.3 & & 10.90 \\
\hline New Zealand & 89 & 81.2 & 6.6 & 9.41 \\
\hline Norway & 73 & 81.4 & 6.7 & 8.93 \\
\hline Poland & 57 & 76.9 & 4.7 & 6.38 \\
\hline Portugal & 49 & 80.8 & 9.4 & 9.09 \\
\hline \multicolumn{5}{|l|}{ Slovak } \\
\hline Republic & 62 & 76.1 & & 7.53 \\
\hline Slovenia & 60 & 80.1 & 5.2 & 8.76 \\
\hline Spain & 75 & 82.4 & 7.8 & 9.02 \\
\hline Sweden & 80 & 81.9 & 4.5 & 11.10 \\
\hline Switzerland & 81 & 82.8 & & 11.36 \\
\hline Turkey & 67 & 74.6 & & 4.40 \\
\hline \multicolumn{5}{|l|}{ United } \\
\hline Kingdom & 77 & 81.1 & 7.6 & 9.86 \\
\hline United States & 90 & 78.7 & & 16.32 \\
\hline
\end{tabular}

Table 2.

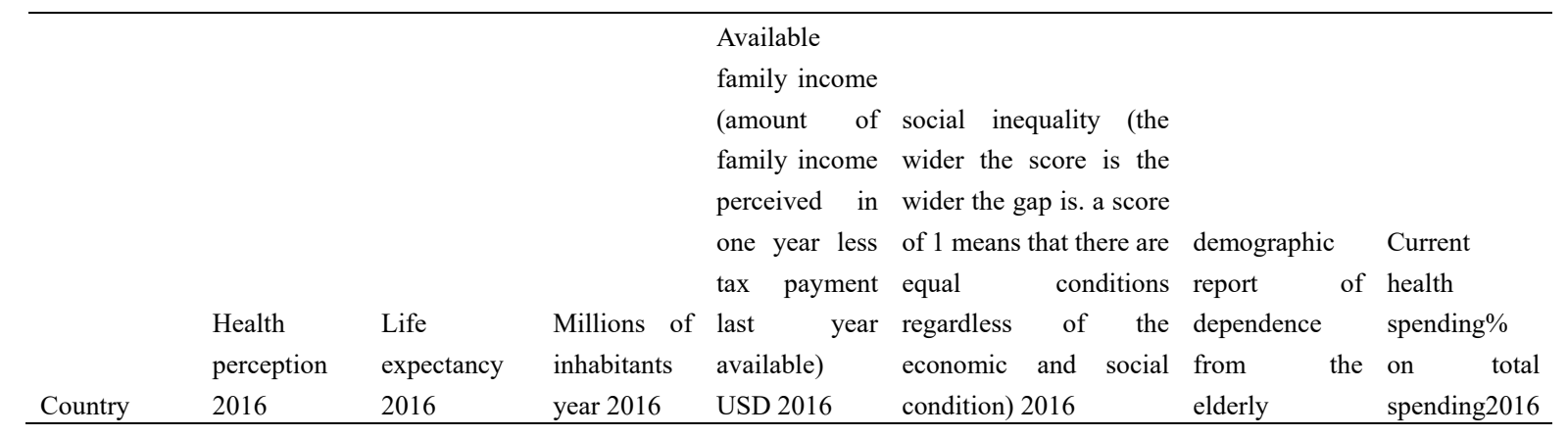




\begin{tabular}{|c|c|c|c|c|c|c|c|}
\hline Australia & 85 & 82.2 & 24127.2 & 33138 & 5.43 & 24.5 & 9.6 \\
\hline Austria & 69 & 81.2 & 8690.1 & 31667 & 4.36 & 30.1 & 10.4 \\
\hline Belgium & 74 & 80.7 & 11311.1 & 28700 & 4.02 & 31 & 10.4 \\
\hline Canada & 89 & 81.5 & 36286.4 & 30474 & 5.17 & 25.1 & 10.3 \\
\hline Chile & 59 & 78.8 & 18191.9 & 15094 & 13.02 & 16.8 & 8.5 \\
\hline \multicolumn{8}{|l|}{ Czech } \\
\hline Republic & 60 & 78.3 & 10553.8 & 18953 & 3.65 & 27.1 & 7.2 \\
\hline Denmark & 72 & 80.4 & 5707.3 & 26945 & 3.59 & 31.5 & 10.4 \\
\hline Estonia & 53 & 77.3 & 1315.9 & 16565 & 5.44 & 29.9 & 6.7 \\
\hline Finland & 65 & 81.1 & 5487.3 & 28238 & 3.74 & 34 & 9.4 \\
\hline France & 67 & 82.3 & 66760 & 29759 & 4.67 & 31.9 & 11.0 \\
\hline$\underline{\text { Germany }}$ & 65 & 80.9 & 82175.7 & 31925 & 4.43 & 35 & 11.3 \\
\hline Greece & 74 & 81.4 & 10783.8 & 18099 & 6.29 & 32.9 & 8.2 \\
\hline Hungary & 57 & 75.7 & 9830.5 & 15614 & 4.53 & 27.8 & 7.6 \\
\hline Iceland & 77 & 82.1 & 332.5 & 27918 & 3.58 & 22 & 8.6 \\
\hline Ireland & 82 & 81.1 & 4724.7 & 22969 & 4.67 & 20.6 & 7.8 \\
\hline Israel & 80 & 82.1 & 8435.1 & 22115 & 7.43 & 19.9 & 7.3 \\
\hline Italy & 66 & 82.8 & 60665.6 & 25004 & 5.56 & 35.9 & 8.9 \\
\hline Japan & 35 & 83.4 & 126932.8 & 27323 & 6.19 & 45.7 & 10.9 \\
\hline Korea & 35 & 81.8 & 51245.7 & 19372 & 5.54 & 19 & 7.7 \\
\hline$\underline{\text { Latvia }}$ & 50 & 74.1 & 1969 & 13655 & 6.51 & 3.3 & 5.7 \\
\hline Luxembourg & 72 & 81.9 & 576.3 & 40914 & 4.05 & 23.1 & 6.3 \\
\hline Mexico & 66 & 74.6 & 121480.5 & 12806 & 13.67 & 11.8 & 5.8 \\
\hline Netherlands & 76 & 81.4 & 16979.1 & 27759 & 4.14 & 29.5 & 10.5 \\
\hline New Zealand & 90 & 81.4 & 4692.7 & 23213 & 5.19 & 24.4 & 9.2 \\
\hline Norway & 76 & 81.8 & 5210.7 & 33393 & 3.73 & 27.4 & 10.5 \\
\hline Poland & 58 & 77.1 & 37967.2 & 17820 & 4.84 & 23 & 6.4 \\
\hline Portugal & 46 & 80.8 & 10341.3 & 19882 & 5.79 & 31.1 & 8.9 \\
\hline \multicolumn{8}{|l|}{ Slovak } \\
\hline Republic & 66 & 76.5 & 5426.3 & 18534 & 3.89 & 20 & 6.9 \\
\hline Slovenia & 65 & 80.4 & 2064.2 & 19130 & 3.61 & 27.6 & 8.6 \\
\hline Spain & 72 & 83.2 & 46445.8 & 22007 & 6.69 & 29 & 9.0 \\
\hline Sweden & 81 & 82 & 9851 & 28859 & 4.14 & 34.1 & 11.0 \\
\hline Switzerland & 81 & 82.9 & 8327.1 & 35952 & 4.42 & 29 & 12.4 \\
\hline Turkey & 68 & 76.6 & 78741.1 & 13471 & 8.4 & 12.8 & 4.3 \\
\hline \multicolumn{8}{|l|}{ United } \\
\hline Kingdom & 74 & 81.1 & 65382.6 & & & 30.3 & 9.7 \\
\hline United States & 88 & 78.8 & 323127.5 & 41071 & 8.19 & 24 & 17.2 \\
\hline
\end{tabular}

\section{Discussion}

\subsection{Performance Indicators / Health Results}

In trying to measure performance, policy makers and researchers need to define which indicators can be used, and how these are influenced by other variables. The key health policy objectives have been set by many countries and international organizations such as WHO and OECD. Health care services refer to the maintenance of an efficient and fair healthcare system without emphasizing an assessment of the determinants of non-health care. In an assessment of health care performance, the direct operation of the health care delivery system is assessed vis-a-vis and its public goals defined by the level and distribution of personal and public health benefits 
and costs. The assessment of health care services is therefore closely linked to the relationship between healthcare and health, from which the bond between health care and other health determinants. In many healthcare systems, clinical prevention services are used to influence clinically relevant lifestyles, such as reducing the number of smokers to prevent heart disease. Health need is a much broader concept to measure, which requires the need to keep track of non-health determinants and contextual information that will allow a clearer picture of the health of the population. In this case, the main goal is not only the balance between efficiency and fairness, but also a wider vision of health determinants and the relative costs that need to be made available. At present there is an increasing need to be able to influence lifestyles and not just health care. Dimensions related to health care are preferably measurable; system attributes that are related to its functioning and to maintain, restore, or improve health (Arah et al., 2003; Joint Commission, 1997). Table 3 provides an overview of the performance commonly used as analysis dimensions in countries and international agencies. There is undoubtedly some overlap and redundancy in the dimensions reported. The common key dimension seen in all performance frameworks is the effectiveness and quality found, which are the degree of desirable achievement of results, given the proper provision of evidence-based healthcare services to anyone who could benefit but not to those who would not benefit (Arah et al., 2006; Richardson, 2001; Veillard, 2005; Donabedian, 1980; Biancone et al., 2017).

Table 3. Dimensions of health care performance (Arah et al., 2006)

\begin{tabular}{|c|c|c|c|c|c|c|c|c|}
\hline Dimension & UK & Canada & Australia & USA & ECHI & $\begin{array}{l}\text { Commonweath } \\
\text { Fund }\end{array}$ & $\begin{array}{l}\text { World Health } \\
\text { Organization }\end{array}$ & OECD \\
\hline Access & & $\mathrm{x}$ & & & & $\mathrm{x}$ & & \\
\hline Accessibility & $\mathrm{X}$ & $\mathrm{x}$ & $\mathrm{x}$ & $\mathrm{x}$ & & $\mathrm{x}$ & & $\mathrm{x}$ \\
\hline Applicability & & $\mathrm{x}$ & $\mathrm{x}$ & & & $\mathrm{x}$ & & \\
\hline Environment and services care & $\mathrm{X}$ & & & & & & & \\
\hline Proficiency & $\mathrm{X}$ & $\mathrm{X}$ & $\mathrm{X}$ & $\mathrm{X}$ & & $\mathrm{x}$ & & \\
\hline $\begin{array}{l}\text { Effectiveness or attention to health } \\
\text { or clinical attention }\end{array}$ & $\mathrm{X}$ & $\mathrm{x}$ & $\mathrm{x}$ & $\mathrm{x}$ & $\mathrm{x}$ & $\mathrm{x}$ & & $\mathrm{X}$ \\
\hline Expense or cost & & & & & & & $\mathrm{x}$ & $\mathrm{X}$ \\
\hline Effectiveness & & $\mathrm{X}$ & $\mathrm{X}$ & $\mathrm{X}$ & & & $\mathrm{X}$ & $\mathrm{X}$ \\
\hline Equity & $\mathrm{X}$ & $\mathrm{X}$ & $\mathrm{X}$ & $\mathrm{X}$ & & & $\mathrm{X}$ & $\mathrm{X}$ \\
\hline Governance & $\mathrm{X}$ & & & & & & & \\
\hline Centrality of patient & $\mathrm{X}$ & $\mathrm{X}$ & $\mathrm{X}$ & $\mathrm{X}$ & & & $\mathrm{X}$ & $\mathrm{X}$ \\
\hline Attention to responsibility, safety & $\mathrm{X}$ & $\mathrm{X}$ & $\mathrm{X}$ & $\mathrm{X}$ & & & & \\
\hline Sustainability & & & $\mathrm{X}$ & & & & & \\
\hline Rapidity & $\mathrm{X}$ & & & $\mathrm{X}$ & & & & \\
\hline
\end{tabular}

The "OECD Health Care" project, about the Quality Indicators launched in 2002, aims to measure and compare the quality of health services in different countries. A group of experts has developed a set of quality indicators at health systems, which allows to assess the impact of particular factors on the quality of health services. Their approach was to integrate and coordinate the efforts of the international and national bodies of the various participating countries. These efforts provide policy makers and other stakeholders with a set of tools to stimulate transnational learning and evaluate the situation (OECD Health Working Paper No. 23, March 2006, Carinci et al., 2015). Unfortunately, OECD data are updated to 2013, this does not allow comparison with the other indicators chosen for our analysis, but they will be compared with the better life index indicator perception of 2013 well-being and life expectancy in 2013. The expectation of life from different studies is related to the quality of the performance provided (Kaplan \& Bush, 1982; Wilson \& Cleary; 1995; Bloom \& Canning, 2000; Marmot \& Bell, 2012), in our analysis it is therefore the only updated parameter in programming and trend for the year 2016. In 2013, the OECD HCQI data collection process included a total of 70 indicators covering the following 'themes': Primary Care (PC); Acuteness care (AC); Mental health (MH); Cancer Care (CC); patient safety (PS) and patient experience (PE). Collection data come from 34 countries, including non-OECD member states such as Singapore and Latvia (OECD, 2013). In addition to regular data collection, there has been concerted effort on the continuous improvement of definitions and the availability of quality indicators for international comparability of the results achieved by healthcare systems. The new indicators have been tested by a pilot project and the results have been included in a reference guide used to educate data collection globally. A common goal for the HCQI work programme was also the strengthening of national information 
infrastructures to produce more complex and reliable indicators in a growing number of countries (Oderkirk et al., 2013). The approach outlined in the diagram can be summarized in Figure 1. More attention to the principle of accountability is used to orient the future activities of the project on the basis of expert recommendations to promote the production of HCQI indicators in the evaluation of health performance systems. To this end, the research team produced a benchmark panel that is periodically updated by the participating nations and entities, called the OECD Health Statistics database in the Health Care Quality Indicators dataset in OECD.Stat. The dataset will be used by the research group for the analysis and the proposed methodological approach.

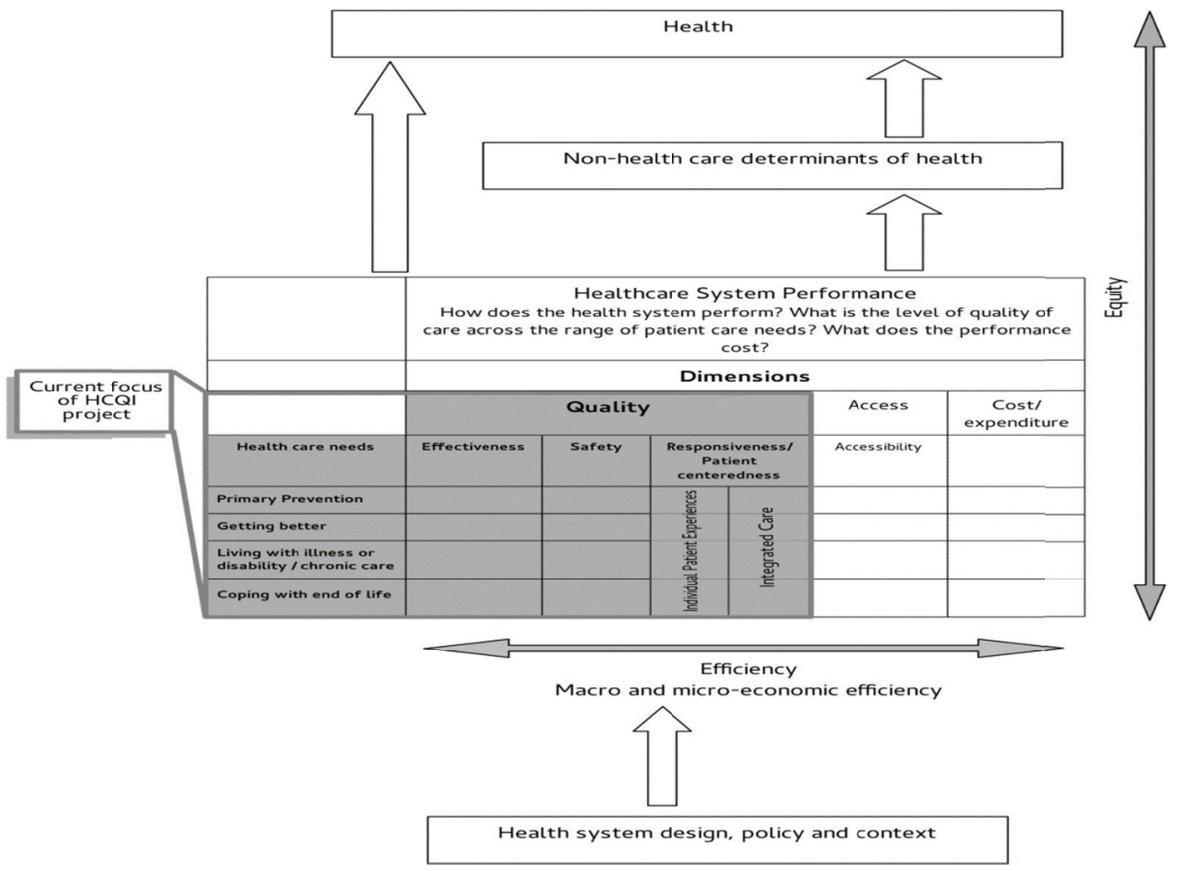

Figure 1. Towards actionable international comparisons of health system performance: expert revision of the OECD framework and quality indicators (Carinci et al., 2015).

\subsection{Sustainable Equal Well-Being Measures - OECD Better Life Index}

For some time, you have been talking about the extent of social well-being, wealth is not the only important criterion or other elements, such as the balance between work and private life, must be considered. The purpose of these measurements is to involve citizens in the debate and to give them the means to be more informed and participate in decisions that affect the lives of all of us. Since its founding in 1961, the OECD has helped public authorities to formulate better policies for a better life. Recently, the OECD has been actively involved in the debate on the measure of well-being. Based on the work carried out, the 11 selected criteria represent what the OECD considers as essential elements for well-being in terms of material living conditions (housing, income, work) and quality of life (social relations, education, environment, governance, health, personal satisfaction, security, relationship between private life and work). Each theme is based on specific indicators, which can range from one to four. The theme of work, for example, is the function of four particular indicators: employment rate, long-term unemployment rate, employee income, workplace guarantee. For each indicator, it is also possible to compare the results between men and women and see to what extent the socio-economic conditions affect the results. In the future, these indicators, which represent the current quality of life and living conditions, will be joined by others who define well-being and sustainability over time. The OECD Better Life Index indicator covers the 34 member-countries of the Organization for Economic Co-operation and Development (OECD), which includes most of the developed countries, emerging countries and two partner countries, Brazil and Russia. In the future, the index will take into account four other OECD partner countries: China, India, Indonesia and South Africa. Each of the 11 themes that make up the indicator is currently based on some indicators (one to four), of which the average is calculated with identical weights. Indicators have been chosen on the basis of various statistical criteria, such as pertinence (apparent validity, precision, usefulness for public intervention) and data quality (predictive validity, scope, adequacy, international comparability, etc.) and in collaboration with OECD member countries. These indicators provide a good measure of the concept of 
well-being, especially in the context of comparisons between countries. Every other issue will be progressively added to other indicators. As far as the definition and the measure of prosperity are concerned, some countries and cultures may, however, give importance to other aspects (such as spirituality) because of their situation or their history. For this reason, although the framework chosen by the OECD covers the dimensions of wellbeing that are universal and pertinent to all human beings, it may be useful to complete it by adopting national criteria that can provide contextual information specific to what makes life satisfying. Data is mostly derived from official sources such as the OECD, national accounts, UN statistics or national statistics institutes. A couple of indicators are based on the data of the Gallup World Poll survey, made by The Gallup Organization, which conducts opinion polls in more than 140 countries around the world. Over $80 \%$ of the Better Life Index indicators have already been published by the OECD. Indicators to be compared between countries and different dimensions have been standardized. Weighted scores can be provided with a scale from 0 "not important" to 5 "very important" based on the importance that the user can point to to read the data; but this parameter was not taken into account during our analysis. To assess the perceived health in each state, the OECD has achieved a series of descriptive indicators of the level. There are five indicators of the performance of each country, these are: life expectancy, calculated as the average number of years of a person's life; gender inequality comparing country scores with gender, the higher the score the higher the gap is, the score of 1 means that there are equal conditions regardless of time; perceived state of health, percentage of individuals according to whom their health is good or very good in the last year on the total; social inequality, comparing country scores with social inequality, the higher the score, the higher the gap. A score of 1 means that there are equal conditions regardless of the economic or social condition. The social indicators we have taken into account in our analysis are the perception of health for 2016 and the social inequality of each country.

\section{Results}

\subsection{Sample Analysis}

The sample is made up of 35 OECD countries. In 2013, the average perception of population health was 68.58 with a maximum value of 90 in the United States and a minimum value of 30 in Japan. The average perception of health in 2016 by the various countries is 68.37 constant compared to 2013 with a minimum of 35 in Korea and a maximum of 90 in New Zealand. In 2013, we also analysed the average life expectancy of 80.06 years consistent with the trend recorded in 2016 and a minimum of 74 in Mexico and a maximum of 82.8 in Switzerland. Life expectancy in the sample is 80.27 years on average with a minimum of 74 years and a maximum of 83 years. The variable varies considerably with the number of inhabitants. In particular, the total average is 36,633 inhabitants with countries with a maximum population of 332.5 Million and countries with a population of 323.127,5 Million inhabitants. Average family income has an average value of US \$24,657 per year, as it varies from USD 12,806 for Mexico to a maximum of USD 41,071 for the United States. Social inequality among the analysed countries is remarkable, in particular the average value is 5.55 points and allows to perceive the difference between virtuous countries where the social difference is as small as Iceland, Denmark, Norway, Slovakia, Slovenia and countries where the difference is as high as Mexico and Chile. Finally, the dependency index of new generations on people over 65 years old or older is 26.32 in average. The country with less dependence is Latvia with 3.3 points, while the country with a higher incidence on the elderly is Japan. The current health expenditure recorded in total spending in percentage terms for the year 2013 is expected to average 9 percentage points. The proportion of current health spending on the total outflow of each state sees an average of 8.98 percentage points on the total with states spending less on current spending such as Turkey with 4.3 percentage points and countries that invest heavily in current health spending as the United States followed by Switzerland; around the average we find most OECD countries in 2016.

\subsection{Social and Quality Indicators, Possible Correlations}

From the statistical analysis, there is a correlation between the 2013 life expectancy indicator and the OECD framework and quality indicators, i.e. the higher-quality structures evaluated according to the quality indicator OECD HCQI in the healthcare sector have a positive impact on life expectancy of the residents of the different countries (standard error $=0.0752 \mathrm{p}$ value $=0.003$ and $\mathrm{R} 2=0.3487$ ). The analysis excludes the possible correlation between the perception of health and the quality component indicator, also considering the independent life expectancy indicator ( $p$ value $>0.05$ ). There is no significant relationship between the percentage of current spending in healthcare as a percentage of the total expenditure of each country and the quality indicator in each country, the same is true between the percentage of spending and life expectancy for 2013 ( $p$ value $>0.05$ ). The analysis shows that the perception of health increases as household income increases (standard error $0.0004496, \mathrm{p}$ value $=0.014$ and $\mathrm{R} 2=0.3499$ ), also considering other independent indicators such as life expectancy, millions of inhabitants, social inequality that are not significantly correlated. If you consider 
only the relationship between the Health Indicator 2016 and the percentage of current health spending on total spending of each country we have a growing correlation, the increase in the health indicator is directly related to the current health expenditure percentage on total expenditure in each state (standard error 0.674 with a $p$ value $=$ $0.003 \mathrm{R} 2=0.137$ ). Given the significance variation between 2013 and 2016 relative to the relationship between the perceived benefit indicator and the percentage of current expenditure on total expenditure of each state, it is possible to assume that the indicator is not really related to expenditure and that depends on other variables. Probably current spending does not always have a real impact on service perception and is not linked to the quality indicator, so it is not said that more spending automatically improves also service quality and user perception.

\section{Conclusions}

The highlighted parameters can be useful for the analyses and the creation of future programming. The analysis of the perception of health in the OECD project "Better life index" states is not correlated with other parameters such as life expectancy, social inequality, number of inhabitants, ratio of total health spending to total spending. There could be a correlation between income availability and therefore spending on each family and perception of health. In this case, perception of health may be affected by an economic variable such as family average spending capacity, and so to a GDP variable on which the state may have a significant impact. It must be considered that it is difficult to affect the variable linked to the average income without affecting the other variables of GDP. The HCQI index is a valid tool to analyse the effective quality of healthcare facilities but has no immediate repercussion on the perception of health by the population, while affecting the life expectancy of the population. Unfortunately, being a composite indicator, the HCQI indicator is currently updated two to three years after programming and allocating resources, this may not have a real usefulness in health planning. As already pointed out, not all social indicators have a relationship with the repercussion of spending and other variables that might be considered when it comes to services provided by public administration (Biancone et al 2017).

\section{Limitations}

The analysis should be conducted for a number of years in order to confirm what is highlighted.

\subsection{Future Perspectives}

The HCQI index being a compound indicator, even if updated two or three years later, can be useful in order to better define the balance between allocating resources to the variables that make it and life expectancy. The study of the repercussion of these variables on life expectancy can identify the right ingredients at both OECD and single country level based on the epidemiological trend and the present health system.

\section{References}

Alfiero, S., \& Secinaro, S. (2010). The financial market turmoil of 2008 has challenged Public Sector (governmental) reporting agencies as well as those in the for-profit sector. Many states are struggling to finance existing services to citizens and this is being exacerbated by the tax bas. International Journal of Public Information Systems, 6(1).

Arah, O. A., Custers, T., \& Klazinga, N. S. (2003). Updating the key dimensions of hospital performance: the move towards a theoretical framework.

Arah, O. A., Westert, G. P., Hurst, J., \& Klazinga, N. S. (2006). A conceptual framework for the OECD health care quality indicators project. International Journal for Quality in Health Care, 18(suppl 1), 5-13. https://doi.org/10.1093/intqhe/mzl024

Berntzen L. (2013). Citizen-centric eGovernment Services. The Sixth International Conference on Advances in Human oriented and Personalized Mechanisms, Technologies, and Services (CENTRIC), 2013, October 27th-November 1st, Venice, Italy, pp. 132-136. https://doi.org/10.1109\%2Fcentric.2010.5

Biancone P., Secinaro S., \& Brescia, V. (2016). Popular report and Consolidated Financial Statements in public utilities. Different tools to inform the citizens, a long journey of the transparency. International Journal of Business and Social Science, 7(1).

Biancone, P., Secinaro, S., \& Brescia, V. (2016). The Popular Financial Reporting: Focus on Stakeholders-The first European Experience. International Journal of Business and Management, 11(11). http://dx.doi.org/10.5539/ijbm.v11n11p115

Biancone, P. P., Secinaro, S., \& Brescia, V. (2017). Popular financial reporting: Results, expense and welfare markers. African Journal of Business Management, 11(18), 491-501. https://doi.org/10.5897/ajbm2017.8367 
Biancone P., Vania T., Brescia V., \& Migliavacca A. (2017), Quality and control in thehealthcare: a win-win mix? International Journal of Business and Social Science, 8(7).

Blanchflower, D. G., \& Oswald, A. J. (2004). Well-being over time in Britain and the USA. Journal of public Economics, 88(7), 1359-1386. https://doi.org/10.1016/s0047-2727(02)00168-8

Bloom, D. E., \& Canning, D. (2000). The health and wealth of nations. Science, 287(5456), 1207-1209. https://doi.org/10.1126/science.287.5456.1207

Borgonovi, E. (1984). Introduzione all'economia delle amministrazioni pubbliche.

Borgonovi, E. (2004). Ripensare le amministrazioni pubbliche. Milano: Egea.

Calabrò F., \& Della Spina, L. (2016). la dimensione sociale della sostenibilità e la sfida di un nuovo umanesimo per le città metropolitane. LaborEst 12

Carinci, F., Van Gool, K., Mainz, J., Veillard, J., Pichora, E. C., Januel, J. M., ... \& Klazinga, N. S. (2015). Towards actionable international comparisons of health system performance: expert revision of the OECD framework and quality indicators. International Journal for Quality in Health Care, 27(2), 137-146. https://doi.org/10.1093/intqhe/mzv004

Stiglitz, J. E., Sen, A., \& Fitoussi, J. (2009). Report by the Commission on the Measurement of Economic Performance and Social Progress.

Costa, A., \& Tafuro, A. (2013). Alcune indicazioni di policy per un'efficiente ed efficace governance dei Gruppi di Azione Locale (GAL). Azienda Pubblica, 26(3), 357-380.

Cristofoli, D., Ditillo, A., Liguori, M., Sicilia, M., \& Steccolini, I. (2010). Do environmental and task characteristics matter in the control of externalized local public services? Unveiling the relevance of party characteristics and citizens' offstage voice. Accounting, Auditing \& Accountability Journal, 23(3), 350-372.

De Carvalho J.F. (2011), Measuring economic performance, social progress and sustainability using an index. Renewable and Sustainable Energy Reviews, 15. https://doi.org/10.1016/j.rser.2010.11.040

Ditillo, A., Liguori, M., Sicilia, M., \& Steccolini, I. (2014). Control patterns in contracting- out relationships: it matters what you do, not who you are. https://doi.org/10.1111/padm.12126

Donabedian, A. (1980). The definition of quality and approaches to its assessment (Vol. 1). Health Administration Press.

Donabedian, A. (1980). Methods for deriving criteria for assessing the quality of medical care. Medical care Review, 37(7), 653.

Epstein, M. J., \& Palepu, K. G. (1999). What financial analysts want. Strategic Finance, 80(10), 48. https://doi.org/10.2469/faj.v66.n2.5

Farneti G..Il contributo delle aziende municipalizzate alla gestione economica dei servizi pubblici. Prospettive e limiti, 1993, CLUA Edizione Ancona p. 257.

Freeman, R. E. (1984). Strategic management: A stakeholder approach. Boston: Pitman. http://dx.doi.org/10.1017/cbo9781139192675.003

Freeman, E. (1994) the politics of stakeholder theory: some future decisions. Business Etichs Quarterly, 4(4) 409-421. http://dx.doi.org/10.2307/3857340

Freeman, E. (2001). A stakeholder. approach to strategic management, Handbook of Strategic Management, Blackwell Publishing, Oxford. http://dx.doi.org/10.1017/cbo9781139192675.007

Giovannini, E., Morrone, A., \& Ranuzzi, G. (2009). Oecd, A Framework to Measure the Progress of Societies, Statistics Directorate, Working Paper n. 34 by Jon Hall. https://doi.org/10.1787/5km4k7mnrkzw-en

Graham, C., \& Felton, A. (2006). Inequality and happiness: insights from Latin America. Journal of Economic Inequality, 4(1), 107-122. https://doi.org/10.1007/s10888-005-9009-1

James, L. C., \& Marc, A. R. (n.d.). The role of information in a democracy and in government operations: the public chose methodology.

Kaplan, R. M., \& Bush, J. W. (1982). Health-related quality of life measurement for evaluation research and policy analysis. Health psychology, 1(1), 61. https://doi.org/10.1037/0278-6133.1.1.61

Keiner, M. (Ed.). (2006). The future of sustainability. Amsterdam: Springer. 
Kosack, S., \& Fung, A. (2014). Does transparency improve governance? Annual Review of Political Science, 17, 65-87.

Leunig, T. (2011). Measuring economic performance and social progress. European Review of Economic History, 15(2), 357-363. https://doi.org/10.1017/s1361491611000086

Marmot, M., \& Bell, R. (2012). Fair society, healthy lives. Public Health, 126, S4-S10. https://doi.org/10.1016/j.puhe.2012.05.014

Morrone, A., Tontoranelli, N., \& Ranuzzi, G. (2009). How good is trust? Measuring trust and its role for the progress of societies, OECD Statistics Working Paper, 2009/03, OECD, Paris.

Mosadeghrad, A. M. (2012). A Conceptual Framework for Quality of Care. Mater Sociomed, 24, 251-261. https://doi.org/10.5455/msm.2012.24.251-261

Oderkirk, J., Ronchi, E., \& Klazinga, N. (2013). International comparisons of health system performance among OECD countries: opportunities and data privacy protection challenges. Health Policy, 112(1), 9-18. https://doi.org/10.1016/j.healthpol.2013.06.006

OECD (2013). Health at a Glance 2013: OECD Indicators. OECD Publishing, 2013. Retrieved from http://www.oecd.org/els/health-systems/Health-at-a-Glance-2013.pdf

Preker, A. S., \& Harding, A. (Eds.). (2003). Innovations in health service delivery: the corporatization of public hospitals (Vol. 434). World Bank Publications.

Puddu, L. (2001). Ragioneria Pubblica. Il bilancio degli enti locali, 2001, Giuffrè, Milano.

Rainero, C., \& Brescia, V. (2016). Corporate Social Responsibility» and «Social Reporting»: The Model of Innovation «Piedmont Method. (2016). International Journal Series in Multidisciplinary Research (IJSMR), 2(3), 18-40.

Richardson, W. C., Berwick, D. M., Bisgard, J. C., Bristow, L. R., Buck, C. R., \& Cassel, C. K. (2001). Crossing the quality chasm: A new health system for the 21st century. https://doi.org/10.1136/bmj.323.7322.1192

Sancino A. (2010). L'attuazione del paradigma della public governance negli enti locali: implicazioni per il management. Economia Aziendale Online, 1(1), 49-58.

Shaker, R. R., \& Zubalsky, S. L. (2015). Examining patterns of sustainability across Europe: a multivariate and spatial assessment of 25 composite indices. International Journal of Sustainable Development \& World Ecology, 22(1), 1-13. https://doi.org/10.1080/13504509.2014.923058

Stiglitz, J. E., Sen, A., Fitoussi, J. P. (2009). Report by the Commission on the Measuring of Economic Performance and Social Progress.

Tanese, A. (2005). Responsabilità sociale d'impresa e sviluppo locale: un impegno comune pubblico-privato. Notizie di Politeia, 78, 296-299.

UNESCO. (2009). The 2009 UNESCO framework for cultural statistics (FCS), 35 C/INF.20, UNESCO, Paris.

Veillard, J., Champagne, F., Klazinga, N., Kazandjian, V., Arah, O. A., \& Guisset, A. L. (2005). A performance assessment framework for hospitals: the WHO regional office for Europe PATH project. International Journal for Quality in Health Care, 17(6), 487-496. https://doi.org/10.1093/intqhe/mzi072

Wilson, I. B., \& Cleary, P. D. (1995). Linking clinical variables with health-related quality of life: a conceptual model of patient outcomes. Jama, 273(1), 59-65.

\section{Copyrights}

Copyright for this article is retained by the author(s), with first publication rights granted to the journal.

This is an open-access article distributed under the terms and conditions of the Creative Commons Attribution license (http://creativecommons.org/licenses/by/4.0/). 